\title{
Therapeutic potential of a novel combination of Curcumin with Sulfamethoxazole against carbon tetrachloride-induced acute liver injury in Swiss albino mice
}

\author{
Rasha Fekry Zahran ${ }^{1 *}$ (D), Zeinab M. Geba ${ }^{1}$, Ashraf A. Tabll ${ }^{2}$ and Mohammad M. Mashaly ${ }^{3}$
}

\begin{abstract}
Background: In the current study, we have investigated the effect of each of curcumin (CUR) and sulfamethoxazole (SMX) either separate or mixed together (CUR + SMX) on biochemical, hematological and histological alternations associated with carbon tetrachloride $\left(\mathrm{CCl}_{4}\right)$-induced liver fibrosis in mice.

Results: $\mathrm{CCl}_{4}$, caused changes of several biomarkers, proving its hepatotoxic effects, such as an increase in aminotransferases liver enzymes alanine and aspartate transaminases (ALT, AST), malondialdehyde (MDA), and nitric oxide (NO) formation, with a decrease in superoxide dismutase (SOD), glutathione reductase (GSSG), total antioxidant capacity (TAO), glutathione (GSH), total protein, and albumin, compared to a negative control mice group. Compared to the $\mathrm{CCl}_{4}$ group of mice, the CUR and SMX separate and/or together (CUR + SMX) treatments showed significance in $(p<0.001$ ), ameliorated liver injury (characterized by an elevation of (ALT, AST) and a decrease $(p<0.001)$ in serum albumin and total protein), antioxidant (characterized by a decrease in $(p<0.001)$ MDA, NO; an increase $(p<0.001)$ SOD, GSSG, TAO; and reducing GSH), hematological changes (characterized by a decrease $(p<0.001)$ in white blood cells count and an increase $(p<0.001)$ in platelets count, hematocrit levels, hemoglobin concentration, and $(p<0.05)$ red blood cells count), SDS-PAGE electrophoresis with a decrease in protein synthesis and changes in histological examinations.

Conclusions: CUR and SMX either separate or together (SUR + SMX) may be considered promising candidates in the prevention and treatment of liver fibrosis.
\end{abstract}

Keywords: Fibrosis, Carbon tetrachloride, Curcumin, Sulfamethoxazole, Oxidative stress, Histopathology

\section{Impact statement}

Liver diseases particularly liver fibrosis, cirrhosis, and hepatocellular carcinoma are major health problems worldwide and in Egypt. The current work reports on the impact of the therapeutic potential of curcumin (CUR) and/or sulfamethoxazole (SMX) against carbon

\footnotetext{
*Correspondence: zahran@du.edu.eg; rzahran17@yahoo.com

${ }^{1}$ Department of Chemistry (Biochemistry division), Faculty of Science,

Damietta University, New Damietta, Egypt

Full list of author information is available at the end of the article
}

tetrachloride-induced acute liver injury in Swiss albino mice. We demonstrated the CUR and SMX used separate or mixed together may be promising therapy in the prevention and treatment of liver fibrosis.

\section{Background}

The liver carries out an essential job in the control of various physiological processes and it controls some vital functions, for example secretion, storage, and metabolic activities. It is frequently exposed to different xenobiotic 
and therapeutic agents. It detoxifies exogenous (toxic compounds) and endogenous (waste metabolites) substances of organisms and integrates helpful operators [1]. As far as anyone is concerned, no reports are available regarding actual curative therapy agents for liver disorders or diseases and most of the existing remedies only aid in healing or regeneration of liver [2]. Fibrosis, a general clinical condition, can be seen in various organs, but mostly in the liver. It is regularly connected with the end phase's of chronic inflammatory diseases [3, 4]. Liver fibrosis is the phenomena of the advancementof a hepatic scar because of chronic liver injury, coming about because of complex interconnected changes in cell population, extracellular matrix (ECM), and cytokines $[5,6]$. For this study, fibrosis utilized carbon tetrachloride $\left(\mathrm{CCl}_{4}\right)$-induced animal model $[7,8]$, published reports [9], showed $\mathrm{CCl}_{4}$ as xenobiotic to induce acute and chronic tissue injuries through bio-enactment of the stage I cytochrome P450 enzymes to deliver receptive metabolic trichloromethyl radicals $\left(\mathrm{CCl}_{3}\right)$ and peroxy trichloromethyl radicals $\left(\mathrm{OOCCl}_{3}\right)$. These receptive metabolites have potential to covalently bond with enormous particles, for instance, lipids, proteins, and nucleic acids, pushing them out of their typical crucial usefulness. $\mathrm{CCl}_{4}$ injection lead to an expansion type of free radicals that are chemically highly reactive, and if they do not cause injury or necrosis, they bring about genuine unsafe impacts, such as hepatic fibrosis, copying the oxidative stress that has a fibrogenic effect on hepatic stellate cells (HSC) $[3,5,6,10,11]$. Curcumin, CUR (Fig. 1): 1, 7-bis (4-hydroxy-3-methoxyphenyl) hepta-1, 6-diene-3, 5-dione. $\left(\mathrm{C}_{21} \mathrm{H}_{20} \mathrm{O}_{6}\right.$, molecular weight = 368.38 ) is the most bioactive structure among the curcuminoid chemical compounds that are extracted from the powdered dry rhizome of Curcuma longa Linn (Zingiberaceae), which is a perennial herb widely cultivated in the tropical region of Asia, especially in India [12, 13]. The medicinal value of curcumin has been well recognized. It has been proven that curcumin has anti-cancer [14], chemo preventive effect [15], antioxidant [16], antiproliferative [17], immunomodulatory [18], hepatoprotective [19], and anti-inflammatory properties [20]. Furthermore, CUR has shown to inhibit fibrosis; however, the specific mechanism of curcumin bioactivity still remains unclear [21].

In contrast, the sulfonamides are a chemical family of synthetic organic compounds containing the sulfonamide $\left(-\mathrm{SO}_{2} \mathrm{NH}_{2}\right)$ or substituted sulfonamide functional group [22, 23]. There are many recent reports on the biochemical investigation of many sulfonamides as carbonic anhydrase inhibitors [24], antibacterial and antibiofilm [25], antifungal [26], anticancer [27], and antiinflammatory active agents [28]. Nowadays, many sulfonamide-containing agents are in clinical use, under

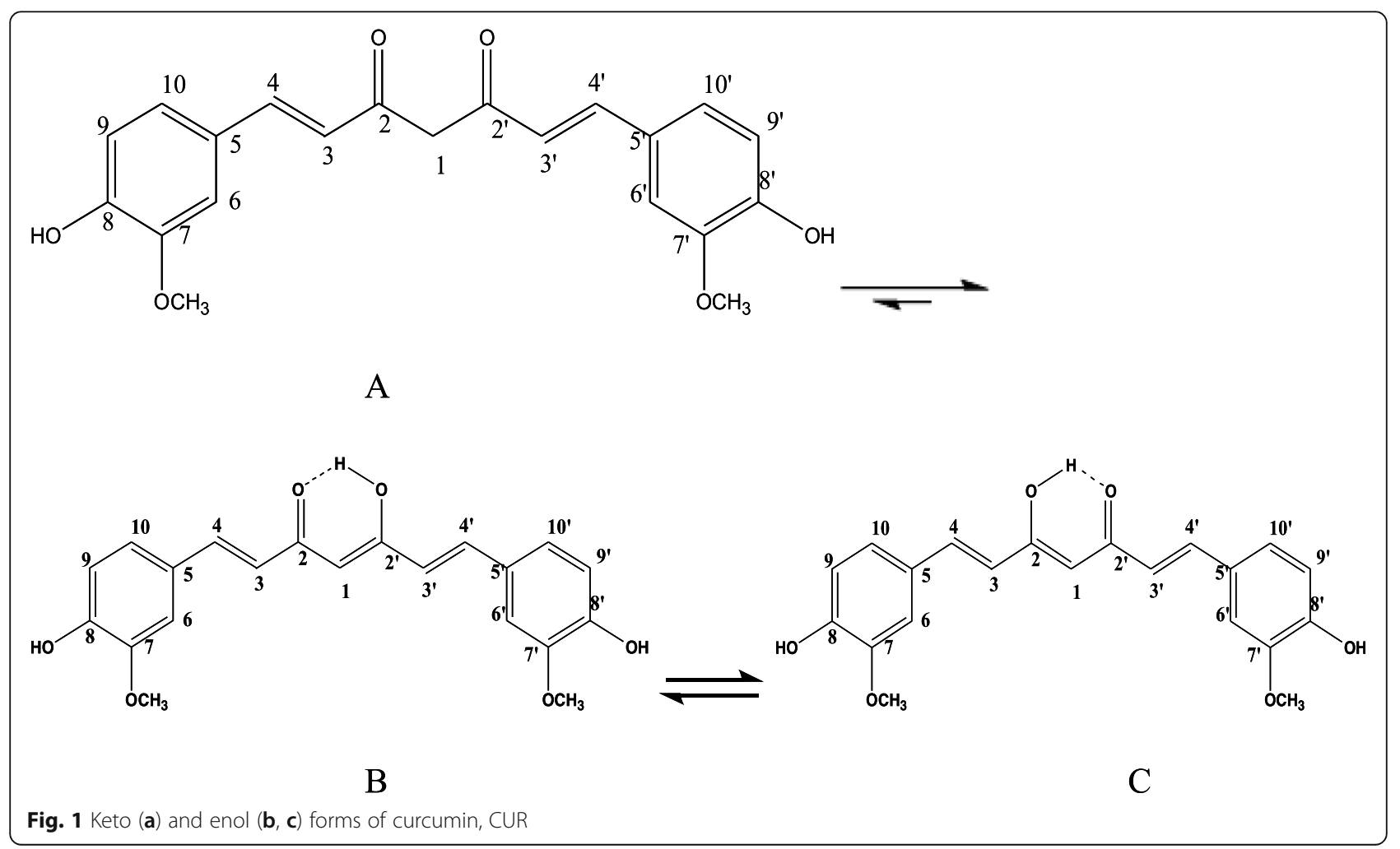


different trade names, in different countries. Some examples of these clinically applied agents, mentioned above are, the tyrosine-kinase inhibitor drug [29], antiinflammatory drug [30], anti-psychotic drug [31], anticancer drug [32], anti-inflammatory drug [33], carbonic anhydrase inhibitor drug [34], anti-diabetes [35], antiarrhythmic [36], anti-glaucoma, antidiuretics, antiepileptics [37], sweeten products [38], and the antibiotic [39]. Moreover, the sulfa drug, sulfamethoxazole (SMX), (Fig. 2) is a well-known antibiotic, acting as a bacteriostatic agent against gram-positive and gram-negative bacteria [40]. It, also, has been reported that low-dose of trimethoprimsulfamethoxazole combination could be a treatment of pneumocystis pneumonia in nonhuman immunodeficiency virus-infected patients, with a low rate of adverse reactions [41].

In this study, we have investigated the effect of each of curcumin (CUR) and sulfamethoxazole (SMX) either separate or together (CUR + SMX) on induced liver fibrosis of carbon tetrachloride $\left(\mathrm{CCl}_{4}\right)$, and induced acute liver injury in Swiss albino mice. The study, also, included an investigation of the effects of these, previously mentioned, compounds on biochemical, hematological, and histological alternations associated with carbon tetrachloride $\left(\mathrm{CCl}_{4}\right)$-induced liver fibrosis in mice.

\section{Methods}

\section{Chemicals}

All reagents and solvents were of high quality and were purchased from commercial sources and were used as received. $\mathrm{CCl}_{4}$ was purchased from $\mathrm{BDH}$ Chemicals, Ltd., Poole, England. $\mathrm{CCl}_{4}$ was diluted 1:1 with Virgin Olive Oil. SMX, Boric acid powder, and Vanillin were purchased from El-Gomhouria Company for Drugs and Chemicals, Egypt. Dimethyl sulfoxide (DMSO), Ethanol, $\geq 99.8 \%$ (GC), n-Butyl amine, 99.5\% and Ethyl acetate, $\geq$ 99.5\% (GC) were purchased from Sigma-Aldrich Chemical Co., (St Louis, MO, USA). Acetylacetone (2, 4- pentanedione), 99+\%, Triisopropyl borate, $98+\%$, were purchased from ACROS ORGANICS, (Geel, Belgium). Hydrochloric acid, 37\%, extra pure, and sodium sulfate, anhydrous, 99+\%, extra pure were purchased from Fisher Scientific UK. Kits used for the experiments of biochemical studies were purchased from Biodiagnostic Company, Dokki, Giza, Egypt.

\section{Preparation of curcumin (CUR)}

Curcumin, CUR, was prepared according to reported modified methods [42-44].

\section{Analysis of curcumin (CUR)}

The melting point (m.p.) of CUR was measured in an open capillary glass tube on a Gallenkamp melting point apparatus (Gallenkamp and CO, UK) and was uncorrected. Infrared (IR) spectrums of CUR was obtained on Perkin Elmer 1430 spectrophotometer with potassium bromide $(\mathrm{KBr})$ disc, in the wavenumber range of 4000 $400 \mathrm{~cm}^{-1}$. Its ${ }^{1} \mathrm{H}$ nuclear magnetic resonance (NMR) $\left(500 \mathrm{MHz}\right.$, DMSO- $\left.\mathrm{d}_{6}\right)$ and ${ }^{13} \mathrm{C}$ NMR $(125 \mathrm{MHz}$, DMSO- $\mathrm{d}_{6}$ ) spectra were determined on JEOL's NMR spectrometer (500 MHz, Japan), using DMSO- $\mathrm{d}_{6}$ as solvent. Chemical shifts are expressed as $\delta$ values (ppm), using tetramethylsilane (TMS) as an internal standard. The following abbreviations were used to indicate the NMR-signals: s (singlet), d (doublet), and br (broad). Electron impact (EI) mass spectral (MS) analysis at 70 $\mathrm{eV}$ of curcumin was performed on Thermo Scientific Trace DSQ II GC-MS (50-400 m/z), (Waltham, MA) system.

Measuring the melting point and the IR analysis of curcumin were performed at the Chemistry Department, Faculty of Science, Egypt, while its ${ }^{1} \mathrm{H}$ and ${ }^{13} \mathrm{C}$ NMR and MS spectral analysis were performed at the Spectral Analysis Unit, Chemistry Department, Faculty of Science, Egypt.

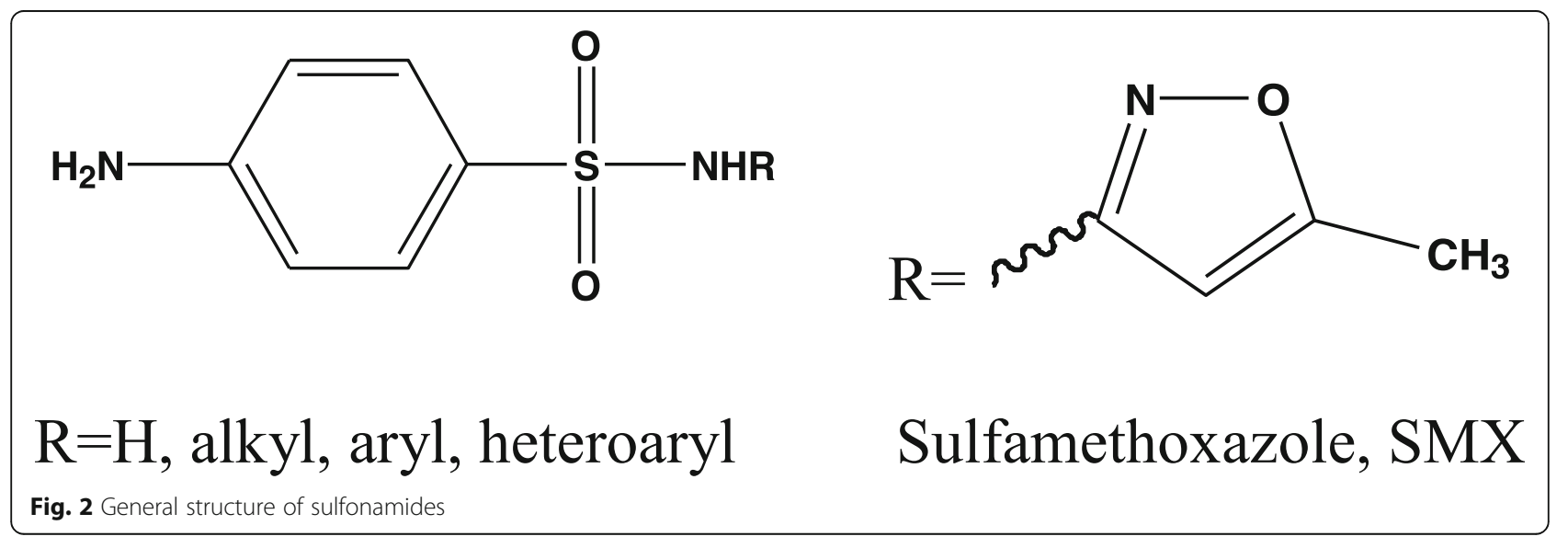




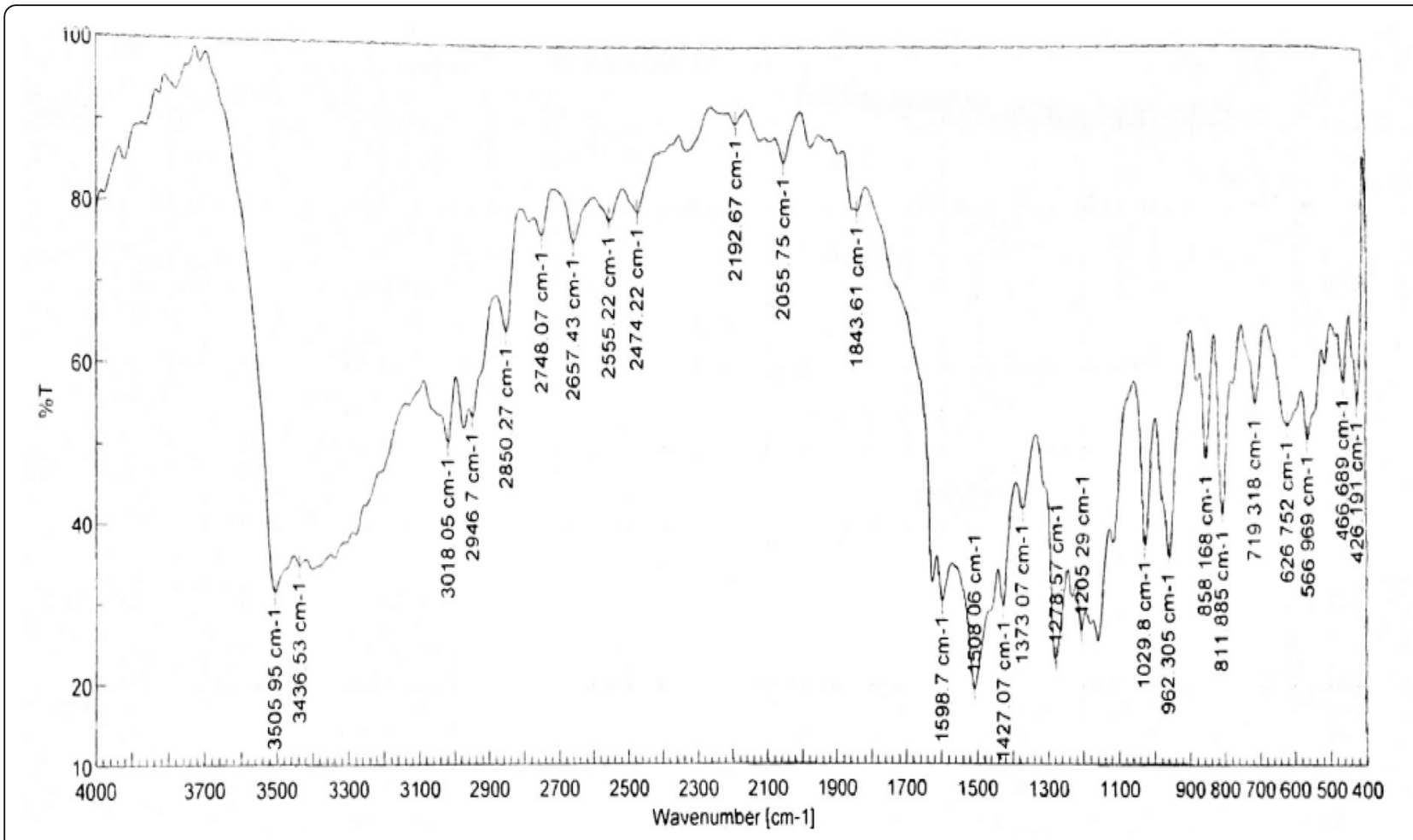

Fig. 3 Infrared spectrum of curcumin

Curcumin (1, 7-bis (4-hydroxy-3-methoxyphenyl) hepta-1, 6-diene-3,5-dione) (Fig. 1)

It was obtained as a yellow-orange crystalline solid; m.p. 180-181 ${ }^{\circ} \mathrm{C}$; IR (KBR, cm ${ }^{-1}$ ) (Fig. 3): 3505.95, 3436.53 $(\mathrm{OH}, \mathrm{H}$-bonded), 3018.05 (C-H aromatic stretching vibration), 2946.70, $2850.27\left(\mathrm{CH}_{2}\right.$ and $\mathrm{CH}_{3}$ asymmetric stretching), $1643.61(\mathrm{C}=\mathrm{O}), 1598.70 \quad(\mathrm{C}=\mathrm{C}$ conjugated with $\mathrm{C}=\mathrm{O}$ ), 1508.06 (benzene ring), 1427.07 (enol $\mathrm{C}-\mathrm{O}$ ), $1373.07\left(\mathrm{CH}_{3}\right.$ bending), 1278.57 (Phenolic $\left.\mathrm{C}-\mathrm{O}\right)$, $1029.80\left(\mathrm{C}-\mathrm{O}-\mathrm{C}\right.$ in $\left.\mathrm{OCH}_{3}\right), 858.17,811.89$ (two adjacent aromatic $\mathrm{C}-\mathrm{H}), 719.32(\mathrm{C}-\mathrm{H}$ vibration aromatic); ${ }^{1} \mathrm{H}$ NMR (DMSO-d 6 , 500MHz) (Fig. 4): $\delta(\mathrm{ppm})=$ 2.11(s, 2H, H-1, keto-form), 6.05 (s, 1H, H-1, enol-form), 6.75(d, 2H, H-3, H-3 ' ) 7.53 (d, 2H, H-4, H-4 ' ), 7.31(d, 2H, H-6, H-6 ' ) , 9.68(s, br, 2H, Ar-OH), 6.80 (d, $\left.2 \mathrm{H}, \mathrm{H}-9, \mathrm{H}-9^{\prime}\right)$, 7.13(dd, 2H, H-10, H-10' ), 3.83(s, $\left.6 \mathrm{H}, \mathrm{OCH}_{3}\right) ;{ }^{13} \mathrm{C} \mathrm{NMR}$ (DMSO-d, $125 \mathrm{MHz}$ ) (Fig. 5): $\delta$ $(\mathrm{ppm})=100.93(\mathrm{C}-1), 183.25\left(\mathrm{C}-1, \mathrm{C}-1^{\prime}\right), 121.11(\mathrm{C}-3$, $\left.\mathrm{C}-3^{\prime}\right), \quad 140.77\left(\mathrm{C}-4, \quad \mathrm{C}-4^{\prime}\right), \quad 126.37 \quad\left(\mathrm{C}-5, \mathrm{C}-5^{\prime}\right)$, 111.31(C-6, C-6 ' ) , 148.02( C-7, C-7' ') 149.37 (C-8, C$\left.8^{\prime}\right), \quad 115.73\left(\mathrm{C}^{\prime} 9, \quad \mathrm{C}^{\prime} 9^{\prime}\right), \quad 123.19\left(\mathrm{C}-10, \quad \mathrm{C}-10^{\prime}\right)$, 55.71 $\left(\mathrm{OCH}_{3}\right) ; \mathrm{MS}: \mathrm{m} / \mathrm{z}=368(0.92 \%)$

\section{Ethics approval and consent to participate}

All animal experiments conformed to the British Home Office Regulations (Animal Scientific Procedures Act 1986) and associated guidelines, EU Directive 2010/63/
EU for animal experiments. This work launched after attaining permission from the scientific and ethical committees of Faculty of Science.

\section{Experimental animals}

Adult male Swiss albino mice (total number, $n=180$ ) were purchased from Zoology Department, Faculty of Science, Egypt, with average weight (25-30 gm each) and housed at the experimental animal house of the Faculty of Science. The animals were maintained in a properly controlled environment of temperature, humidity, and light. The mice were fed with autoclaved chow and filtered water and were adapted for a week prior to experimentation.

\section{Experimental design}

The Swiss male adult albino mice were divided into nine (I-IX) groups (20 mice/each) as shown in Table 1. At the end of the experiment, mice fasted for $12 \mathrm{~h}$ and then blood samples were taken from the heart puncture under light ether anesthesia. Blood samples were collected for biochemical and hematological analysis. Animals were sacrificed and the liver dissected out and washed with isotonic saline and divided into two parts, the first part was stored at $-20{ }^{\circ} \mathrm{C}$ until assay for estimation of antioxidant parameters. The second part of 


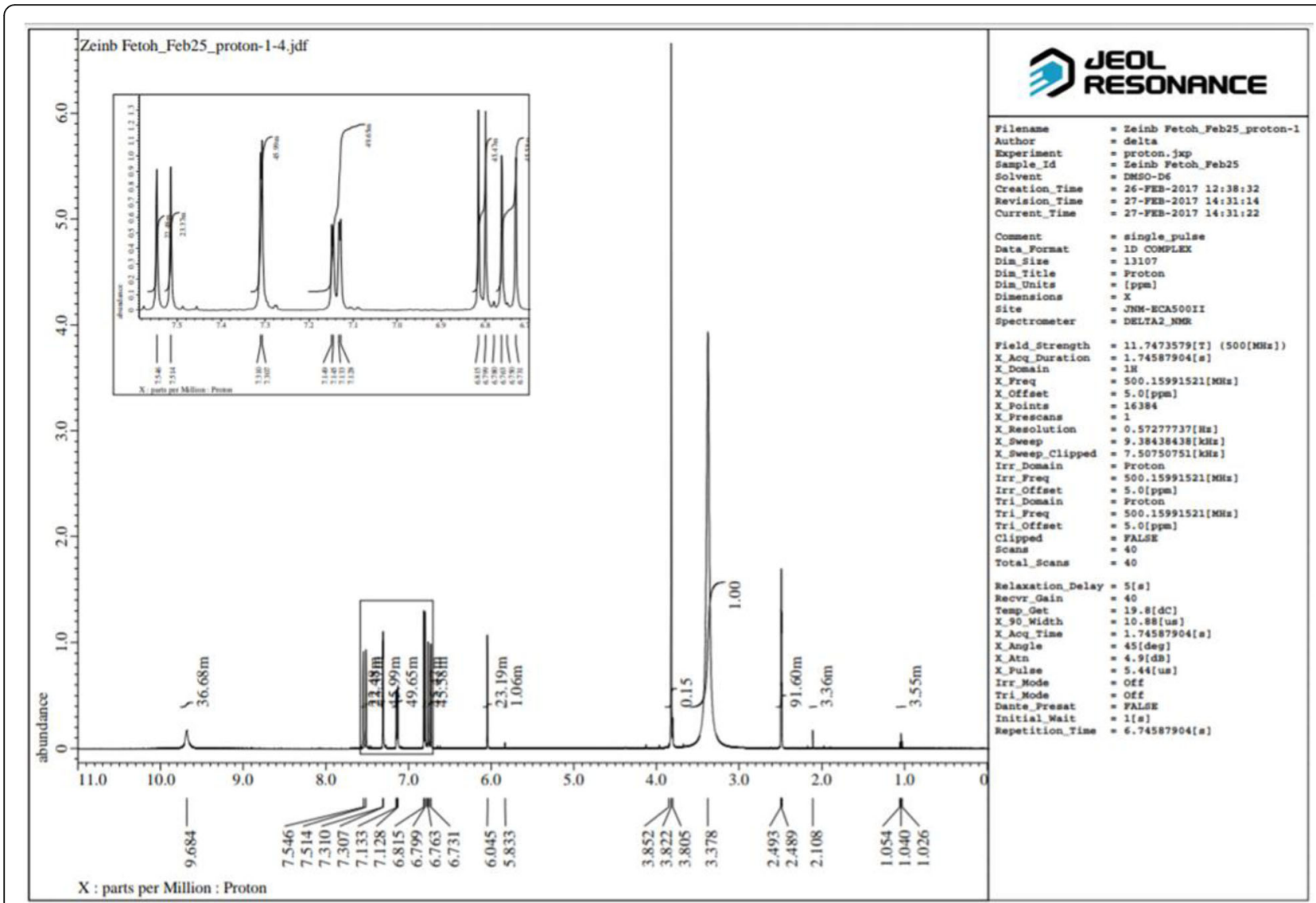

Fig. $4{ }^{1} \mathrm{H}$ NMR $(500 \mathrm{MHz})$ spectrum of curcumin in $d_{6}$-DMSO

the liver tissue was fixed in (10\%) formalin for histopathology assessment.

\section{Biochemical analysis}

Estimation of nitric oxide (NO) level was determined in liver tissues by using Biodiagnostic kit, Egypt (cat. no. NO2533), according to the method of Montgomery and Dymock [48]. Glutathione reductase (GSSG) was determined by using Biodiagnostic kit, Egypt (cat. no. GR2523), according to the method of Goldberg and Spooner [49]. The serum samples were collected for liver function tests. The activities of aspartate transaminase (AST) and alanine transaminase (ALT) were estimated by using Biodiagnostic kits, Egypt (cat. no. AS1061 (45), cat. no. AL1031 (45), according to the method of Reitman and Frankel [50]. Serum total protein and albumin concentrations were estimated by using Biodiagnostic kits, Egypt (CAT.NO. TP2020, cat. no. AB1010), according to the method of Gornall et al. [51] and Doumas et al. [52]. Moreover, plasma samples were collected for antioxidant assays. Estimation of superoxide dismutase (SOD) activity was assayed according to the method of Nishikimi et al. [53]. Glutathione reduced (GSH) was estimated by using a commercial kit (Biodiagnostic
Company, Dokki, Giza, Egypt), according to the method of Beutler et al. [54]. Total antioxidant activity (TAO) carried out according to the method of koracevic et al. [55]. Malondialdehyde (MDA) level was assayed using Biodiagnostic kit, Egypt (cat. no. MD2529), according to the method of Satoh [56] and Rubio et al. [57].

\section{Hematological analysis Complete blood count (CBC)}

A portion of retro-orbital blood samples was collected from each animal used for a complete blood count. Blood cell counts (white blood cells, red blood cells, and platelets) were performed with HORIBA Hematology analyzer (model: MICROS 60 OT) (France).

\section{Sodium dodecyl sulphate polyacrylamide gel electrophoresis (SDS-PAGE)}

Protein fractionation was done by using one-dimensional polyacrylamide gel electrophoresis according to the method of Leammli [58].

\section{Sample preparation}

One gram of each sample (liver tissue) was ground in 1 $\mathrm{ml}$ homogenate buffer $(0.02 \mathrm{M}$ Tris- $\mathrm{HCl} \mathrm{pH} \sim 7.5)$ using 


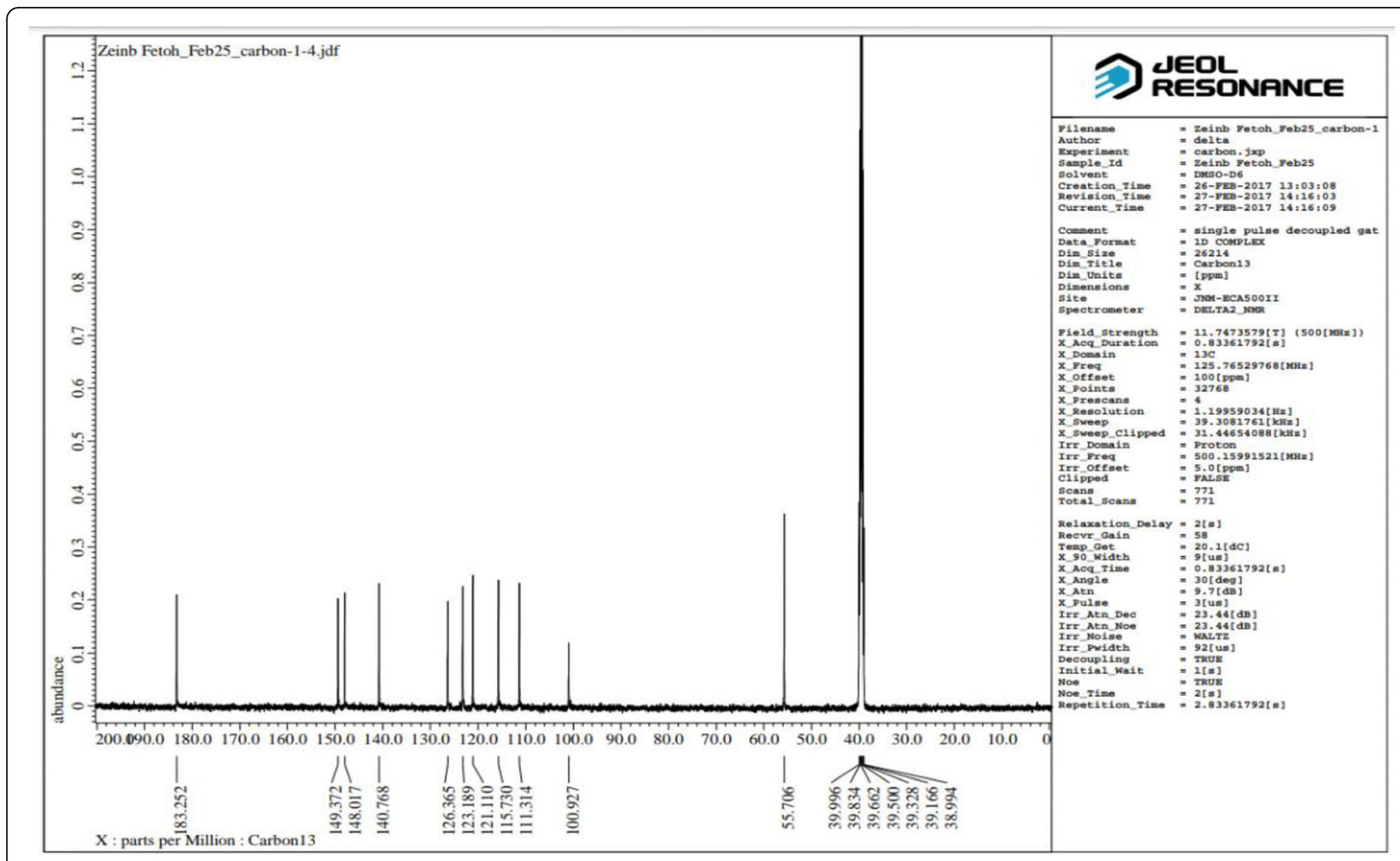

Fig. $5{ }^{13} \mathrm{C}$ NMR $(125 \mathrm{MHz})$ spectrum of curcumin in $\mathrm{d}_{6}$-DMSO

a mortar. The content was transferred to a new Eppendorf tube, centrifuged at $10000 \mathrm{rpm}$ for $10 \mathrm{~min}$ at $4{ }^{\circ} \mathrm{C}$, and then the supernatant was kept frozen at $-20^{\circ} \mathrm{C}$ until required. Protein samples were denatured by boiling in a water bath for 5 min with SDS sample buffer. Then, they were loaded into the wells of gel which was composed of $5 \%$ stacking gel and $12 \%$ polyacrylamide separating gel next to the molecular weight marker protein. The separated protein on the polyacrylamide gel was stained with Coomassie blue R-250 Andrews [59]. After that, the gel

Table 1 Experimental design

\begin{tabular}{|c|c|c|c|}
\hline Groups & Dose & Method of section & Duration \\
\hline Group I negative control & $0.5 \mathrm{ml}$ olive oil $/ \mathrm{kg}$ b.w. & i.p & 3 times a week for 5 weeks \\
\hline Group II DMSO control & (0.2\%) DMSO & i.p & 3 times a week for 4 weeks \\
\hline Group III CCl ${ }_{4}$ control & $1 \mathrm{ml}$ (50\% in olive oil)/kg b.w. & i.p & 3 times a week for 5 weeks \\
\hline Group IV CUR group & $\begin{array}{l}\mathrm{CCl}_{4} \text { as group III followed by CUR } 100 \mathrm{mg} / \mathrm{kg} \text { b.w. } \\
\text { in olive oil }[45,46]\end{array}$ & $\begin{array}{l}\mathrm{CCl}_{4} \text { i.p } \\
\text { CUR orally through a gastric } \\
\text { tube }\end{array}$ & $\begin{array}{l}\mathrm{CCl}_{4} 3 \text { times a week for } 5 \\
\text { weeks then } \\
4 \text { times a week for } 4 \text { weeks }\end{array}$ \\
\hline Group V CUR control & 100 mg/kg b.w. in olive oil $[45,46]$ & orally through a gastric tube & 4 times a week for 4 weeks \\
\hline Group VI SMX Group & $\begin{array}{l}\mathrm{CCl}_{4} \text { as group III followed by } 15 \mathrm{mg} \mathrm{SMX/kg} \mathrm{b.w.} \mathrm{in} \\
\text { DMSO [47] }\end{array}$ & i.p & $\begin{array}{l}\mathrm{CCl}_{4} 3 \text { times a week for } 5 \\
\text { weeks then } \\
4 \text { times a week for } 4 \text { weeks }\end{array}$ \\
\hline Group VII SMX control & 15 mg SMX/kg b.w. in DMS O[47] & i.p & 4 times a week for 4 weeks \\
\hline $\begin{array}{l}\text { Group VIII Combination (CUR + } \\
\text { SMX) group }\end{array}$ & $\begin{array}{l}\mathrm{CCl}_{4} \text { as group III followed by CUR as group } \mathrm{V} \text { and } \\
\mathrm{SMX} \text { as group VII }\end{array}$ & $\begin{array}{l}\mathrm{CCl}_{4} \text { and } \mathrm{SMX} \text { i.p } \\
\text { CUR orally through a gastric } \\
\text { tube. }\end{array}$ & $\begin{array}{l}\mathrm{CCl}_{4} 3 \text { times a week for } 5 \\
\text { weeks then } \\
4 \text { times a week for } 4 \text { weeks }\end{array}$ \\
\hline $\begin{array}{l}\text { Group IX Combination (CUR. + } \\
\text { SMX.) control }\end{array}$ & CUR as group V and SMX as group VII & $\begin{array}{l}\text { CUR orally through a gastric } \\
\text { tube. SMX i.p }\end{array}$ & 4 times a week for 4 weeks \\
\hline
\end{tabular}

$\mathrm{CCl}_{4}$ carbon tetrachloride, CUR curcumin, $\mathrm{SMX}$ sulfamethoxazole, i.p intraperitoneally 
was removed from the distaining solution, placed between two transparent sheets, and was left to air dry. Then, the gel was scanned and analyzed by the Gel-Pro Analyzer program http://meyerinst.com/imaging-software/image-pro/gel/index.htm (Media cybernetics, Georgia, USA).

\section{Histopathological examinations}

Mouse liver tissues were fixed in $10 \%$ neutral formalin, then dehydrated, and further embedded with paraffin. Paraffin-embedded liver samples were sectioned to 3$\mu \mathrm{m}$-thin slices, which were stained with hematoxylineosin (HE) staining and Masson staining according to standard protocols of Oner-lyidogan et al. [60].

\section{Statistical analysis}

Data were evaluated by one-way analysis of variance (ANOVA) by "SPSS" 14.0 for Microsoft Windows, SPSS Inc. and considered statistically significant at a two-sided $p<0.05$. Numerical data were expressed as mean \pm SD .

\section{Results}

Characterization of curcumin

The melting point of curcumin

The prepared curcumin was crystallized from absolute ethanol as a yellow-orange crystalline solid, melting at $180-181{ }^{\circ} \mathrm{C}$ which is effective concur with the literature (m.p $=181-182{ }^{\circ} \mathrm{C},[42,61]$; and $\left.\mathrm{m} . \mathrm{p}=178-182{ }^{\circ} \mathrm{C},[62]\right)$.

\section{Infrared spectroscopy (IR) of curcumin}

The IR spectrum of curcumin is shown in Fig. 3 along with its data and assignments, which are effective and concur with the literature [42, 63-68].

\section{Nuclear magnetic resonance spectroscopy of curcumin}

The ${ }^{1} \mathrm{H}$ and ${ }^{13} \mathrm{C}$ NMR spectra of curcumin are shown in Figs. 4 and 5, respectively. The NMR data of curcumin, whose interpretation confirmed its structure and its effectiveness, concurring with the literature $[42,64,67,68]$.

\section{Mass spectrometry (MS) of curcumin}

The MS analysis has confirmed the structure of curcumin, showing its molecular ion peak at $\mathrm{m} / \mathrm{z}=368$ with a relative intensity of $0.92 \%$.

\section{Curcumin and sulfamethoxazole relieved $\mathrm{CCl}_{4}$-induced on antioxidants in Swiss mice}

The mean value of MDA and NO levels were $58.051+$ $0.92 \mathrm{nmol} / \mathrm{ml}$ and $40.07 \pm 0.71 \mu \mathrm{mol} / \mathrm{l}$, respectively in a group (I, Table 1). The $\mathrm{CCL}_{4}$-positive control group (III, Table 1) showed a significant increase in MDA and NO levels to be $88.83 \pm 0.70 \mathrm{nmol} / \mathrm{ml}$ and $77.08 \pm 0.57$ $\mu \mathrm{mol} / \mathrm{l}$, respectively, $(p<0.001)$ compared to the control group (I, Table 1). Their levels demonstrated a significant decrease in curcumin (IV, Table 1), sulfamethoxazole (VI, Table 1), and their combination group (VIII, Table 1) compared to the $\mathrm{CCl}_{4}$-positive control group (III, Table 1) as shown in Fig. 6a, b. On the other hand, SOD, GSH, GSSG, and TAO activities were decreased $(p<0.001)$ from $157.35 \pm 0.75 \mathrm{U} / \mathrm{ml}, 9.3 \pm 0.54$ $\mathrm{mg} / \mathrm{dl}, 9.9 \pm 0.24 \mathrm{U} / \mathrm{L}$, and $0.18 \pm 0.022 \mathrm{mmol} / \mathrm{L}$ in the negative control group (I, Table 1) to $58.97 \pm 0.65,2.4 \pm$ $0.54,1.6 \pm 0.26,0.064 \pm 0.011$, respectively in $\mathrm{CCL}_{4}$ control group (III, Table $\overline{1}$ ). While their concentration was significantly increased in the curcumin group (IV, Table 1), sulfamethoxazole group (VI, Table 1) and highly increased in the combination group (VIII, Table 1) compared to the $\mathrm{CCL}_{4}$-positive control group as shown in Fig. $6 \mathrm{c}-\mathrm{f}$, respectively.

\section{Curcumin and sulfamethoxazole relieved $\mathrm{CCl}_{4}$-induced on liver enzymes in Swiss mice}

Measurement of liver enzyme activities demonstrated a significant increase in ALT and AST activities in $\mathrm{CCl}_{4}$ positive control group (III, Table 1) to $78.37 \pm 4.3$ and $130.14 \pm 5.0 \mathrm{U} / \mathrm{L}$; respectively, in comparison to the negative control group (I, Table 1) $(p<0.001)$. These high activities of liver enzymes were significantly reduced by curcumin (IV, Table 1), sulfamethoxazole (VI, Table 1), and their combination (VIII, Table 1) in comparison with $\mathrm{CCl}_{4}$-positive control group (III, Table 1), $(p<0.001)$ as in Fig. 7a, b. Also, measurement of total protein and albumin concentration demonstrated a significant decrease in $\mathrm{CCl}_{4}$-positive control group (III, Table 1) to $6.69 \pm 0.24$ and $3.17 \pm 0.28 \mathrm{~g} / \mathrm{dl},(p<0.001)$ in comparison with a negative control group (I, Table 1).These concentrations were significantly increased to $10.48 \pm 0.83$ and $4.79 \pm 0.17$, respectively in $\left(\mathrm{CCl}_{4}+\right.$ CUR) group (IV, Table 1), to $10.42 \pm 0.41$ and $4.50 \pm$ 0.37 in $\left(\mathrm{CCl}_{4}+\mathrm{SMX}\right)$ group (VI, Table 1) and o $10.63 \pm$ 0.36 and $5.03 \pm 0.15$, in $\left(\mathrm{CCl}_{4}+\mathrm{CUR}+\mathrm{SMX}\right)$ group (VIII, Table 1), respectively, compared to $\mathrm{CCl}_{4}$-positive control group (III, Table 1), $(p<0.001)$ as in Fig. 7c, d.

\section{Curcumin and sulfamethoxazole relieved $\mathrm{CCl}_{4}$-induced on hematological changes in Swiss mice}

Red blood cells (RBCs) count, hematocrit (HCT) value, platelets (PLT) count, and hemoglobin (HGB) concentration were significantly decreased to $6.25 \pm 0.29 \times 10^{6}$ / $\mathrm{mm}^{3}$ ( $\left.p<0.05\right), 27.30 \pm 1.27 \%, 523.85 \pm \overline{2} 2.57 \times 10^{3} /$ $\mathrm{mm}^{3}$, and $9.44 \pm 0.51 \mathrm{~g} / \mathrm{dl}(p<0.001)$, respectively. While white blood cells (WBCs) count was significantly increased to $21.02 \pm 2.0 \times 10^{3} / \mathrm{mm}^{3}(p<0.001)$ in the control $\mathrm{CCl}_{4}$-positive control group (III, Table 1) in comparison with the negative control group (I, Table 1). RBCs count, HGB concentration, HCT value, PLT count, and HGB concentration were significantly increased in curcumin group, sulfamethoxazole group, and 


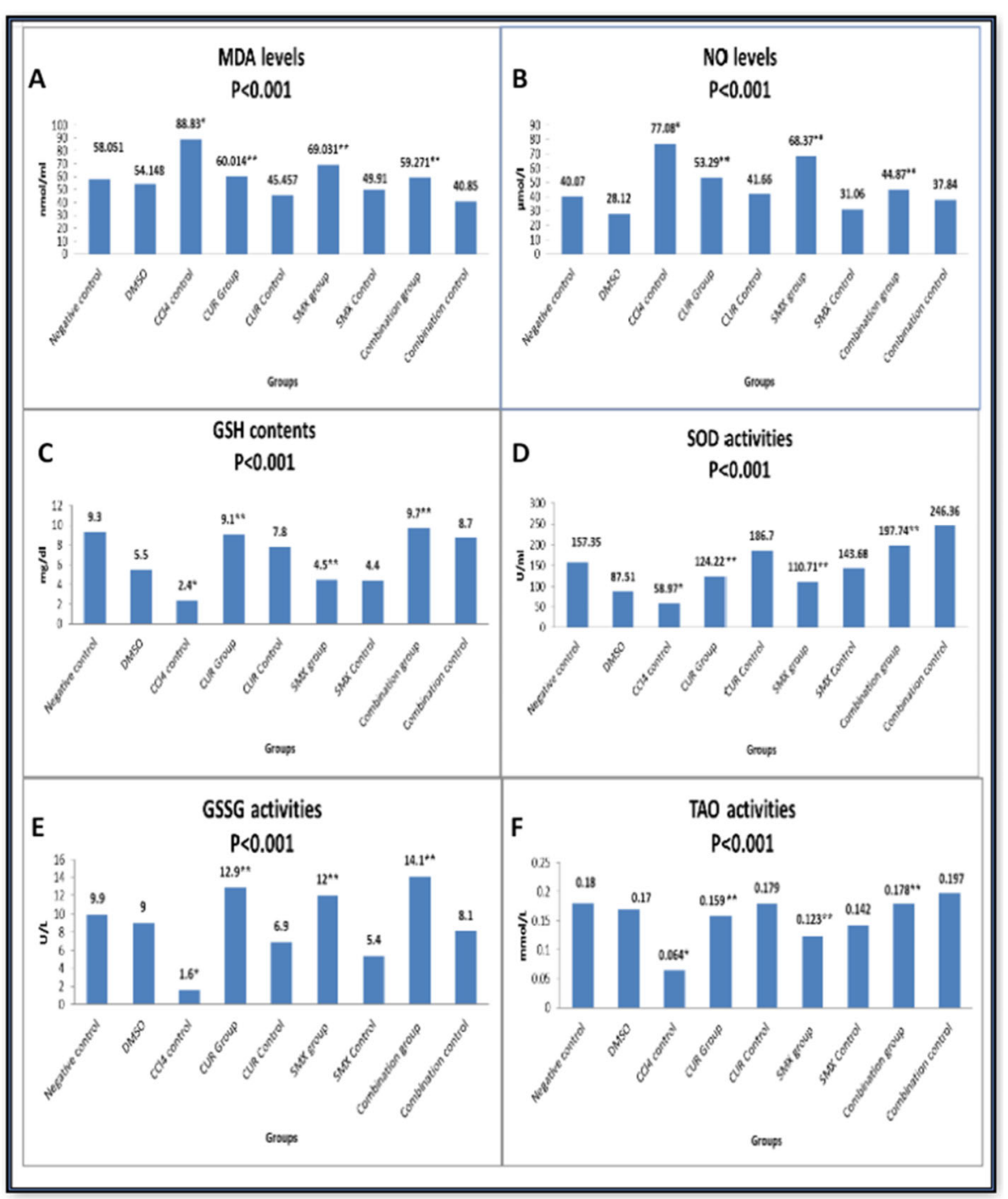

Fig. 6 Effect of curcumin and sulfamethoxazole on antioxidants in all studied groups. a MDA levels, b O levels, c GSH contents, d SOD activities, e GSSG activities, and f TAO activities. Results were expressed as mean. $\left(^{*}\right)$ Compared with normal control, $\left({ }^{* *}\right)$ Compared with $\mathrm{CCl}_{4}$ control showed a highly significant difference from control value at $(p<0.001)$

in combination CUR + SMX group, while WBCs count was significantly decreased in curcumin group (IV, Table 1), sulfamethoxazole group (VI, Table 1), and in combination CUR + SMX group (VIII, Table 1) in comparison with $\mathrm{CCL}_{4}$-positive control group (III, Table 1) as in Fig. 8a-d.

\section{Sodium dodecyl sulphate polyacrylamide gel}

\section{electrophoresis (SDS-PAGE) on liver tissue of Swiss mice}

The electrophotography showed that the protein band, especially at M.wt nearly $53 \mathrm{KDa}$, in $\mathrm{CCL}_{4}$-positive control group (lane-1) completely disappeared in the normal control group (lane-9), DMSO control group (lane-5), curcumin control group (lane-8), sulfamethoxazole control group (lane-7), and combination (curcumin + sulfamethoxazole) control group (lane-6). However, the band partially disappeared in the curcumin group (lane-4), sulfamethoxazole group (lane-2), and combination (curcumin + sulfamethoxazole) group (lane-3) as in Fig. 9.

The gel pro analysis demonstrated that six bands in $\mathrm{CCL}_{4}$-positive control group, three bands in normal control group, three bands in DMSO control group, three bands in sulfamethoxazole control group, three bands in curcumin control group, three bands in combination (curcumin + sulfamethoxazole) control group, four bands in curcumin group, five bands in sulfamethoxazole group, and four bands in combination (curcumin + sulfamethoxazole) group with molecular weight approximately ranged from 11 to $75 \mathrm{KDa}$ as in Fig. 10a-i 


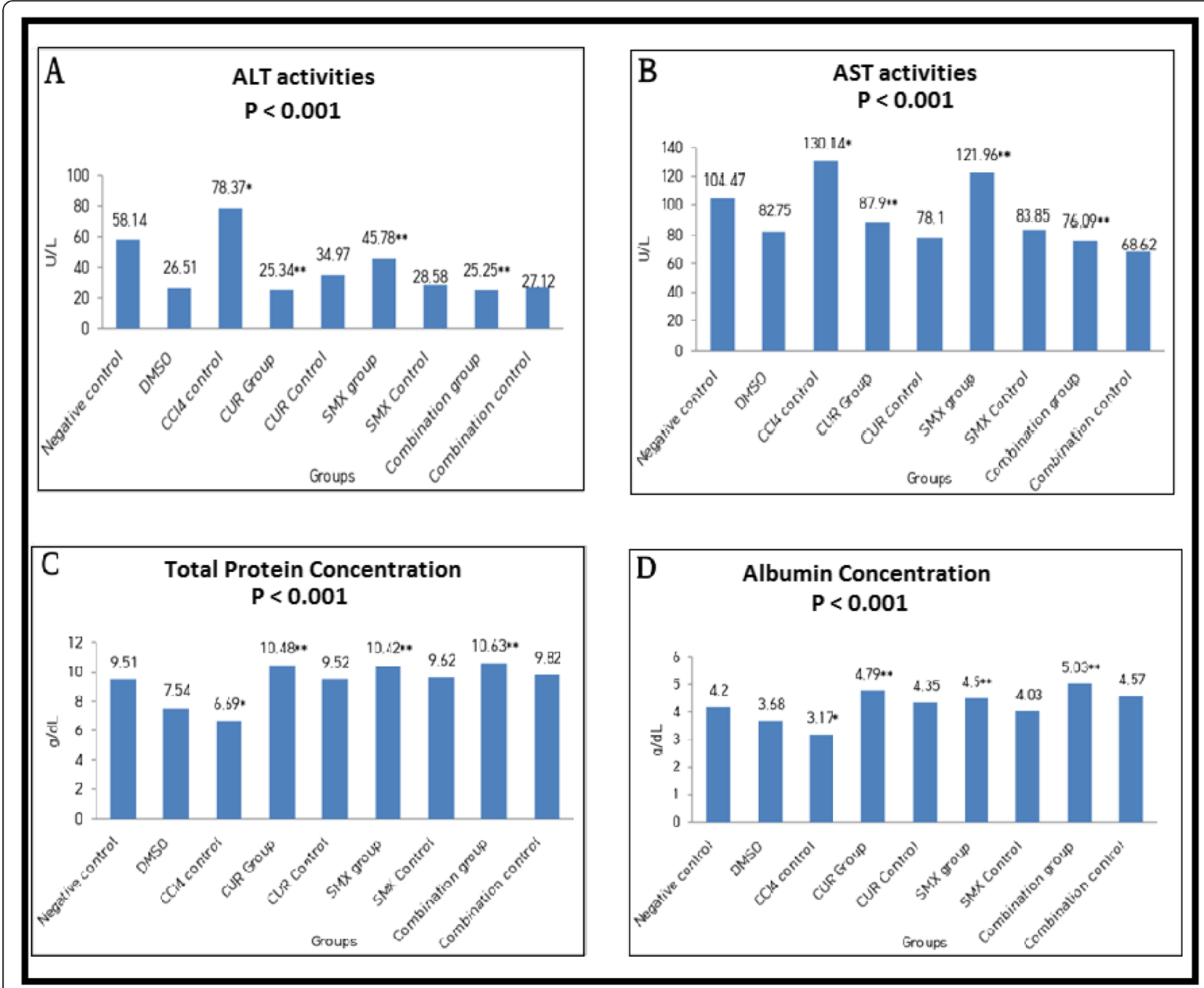

Fig. 7 Biochemical markers of hepatic injury (liver function tests). a ALT activities, b AST activities, c total protein concentrations, and $\mathbf{d}$ albumin concentrations. Results were expressed as mean $\left(^{*}\right)$ compared with normal control, $\left(^{* *}\right)$ compared with $\mathrm{CCl}_{4}$ control, and showed a highly significant difference from control value at $(\boldsymbol{p}<0.001)$

\section{Histopathological studies}

The histological examination of liver tissues in all studied groups confirmed the biochemical study in all different groups (Fig. 11). The histological examination of the control mice group (negative control) (I, Table 1) showed, the normal hepatocytes around the portal area (arrowhead), H\&E, $\times$ 200, (Fig. 11a). The DMSO group (II, Table 1) showed normal liver structures, H\&E, $\times 200$, (Fig. 11b). However, the $\mathrm{CCl}_{4}$ group (III, Table 1) had degenerative changes with an increase number of fibroblasts and fibrosis, H\&E X400, (Fig. 11c). Meanwhile, the curcumin-treated group (IV, Table 1) showed cell swelling of hepatocytes within the centrilobular area (arrow) besides a moderate degree of vacuolation of hepatocytes within the periportal area, H\&E, $\times 200$, (Fig. 11d). While the curcumin control group (V, Table 1) showed normal liver structures, H\&E, $\times 200$, (Fig. 11e). the sulfamethoxazole treated group (VI, Table 1) showed cloudy swelling, vacuolar degeneration of hepatocytes, and mononuclear cells infiltration, H\&E, $\times 200$ (Fig. 11f), while the sulfamethoxazole control group (VII, Table 1) showed normal liver structures, H\&E, $\times 200$, (Fig. 11G). The combined CUR + SMX group (VIII, Table 1) showed cell swelling and mild vacuolization of hepatocytes, H\&E, $\times 200$, (Fig. 11h), while, the combined CUR + SMX control group (IX, Table 1) showed normal liver structures, H\&E, $\times 200$, (Fig. 11i).

\section{Discussion}

Curcumin (CUR) is a widely examined natural compound that has demonstrated imposing in vitro therapeutic potential. Disregarding the way that the experimental efficacy of natural curcumin is frail due to its low bioavailability and high metabolism in the gastrointestinal tract because of its poor solubility in water and quick in liver and intestinal digestion which add to 


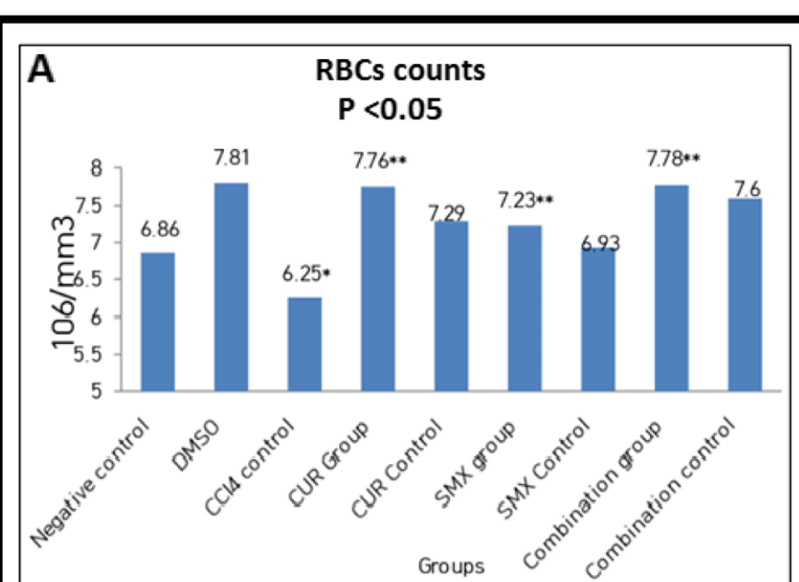

\section{B HGB concentration $P<0.001$}
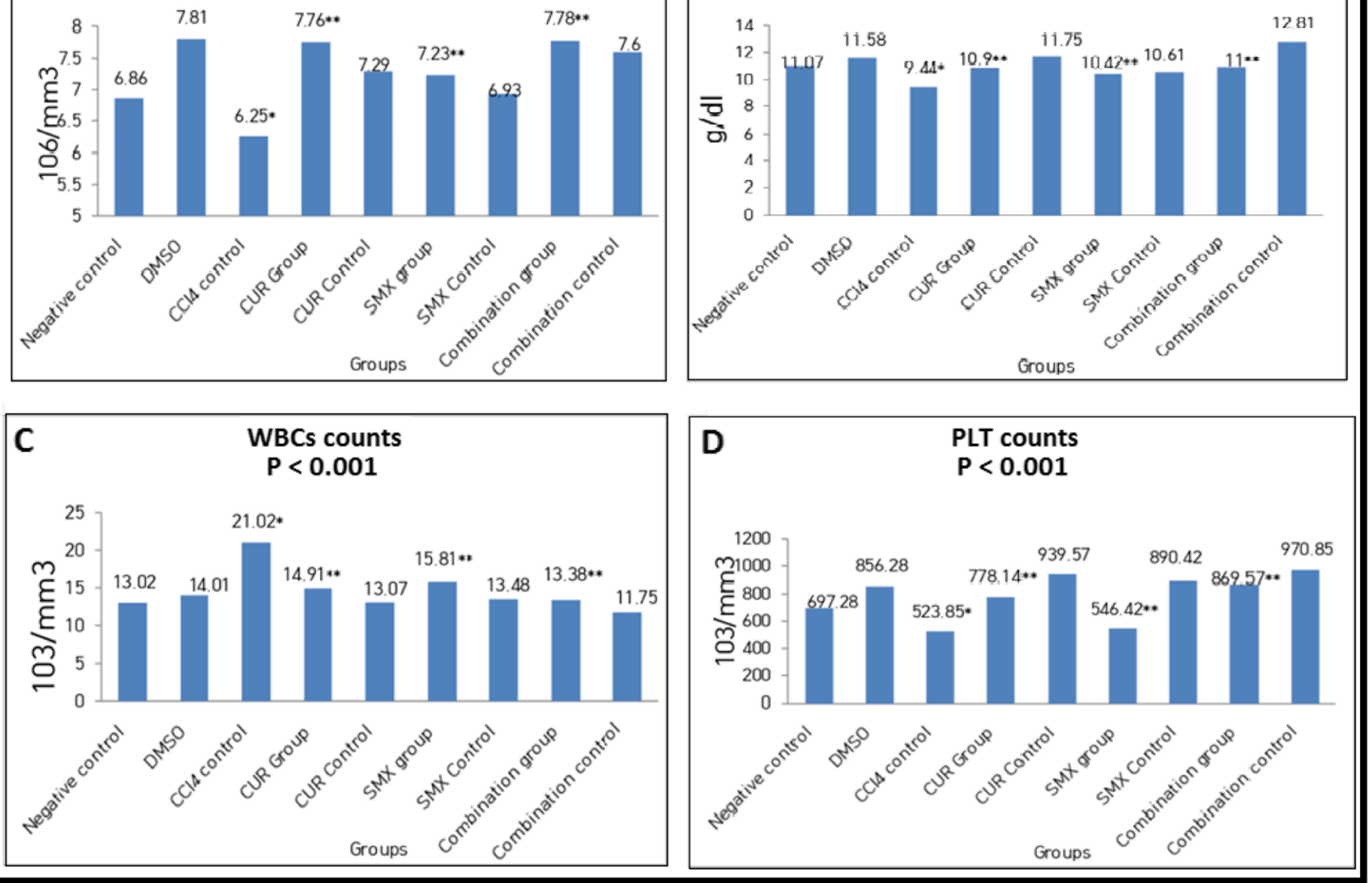

Fig. 8 Effect of curcumin and sulfamethoxazole on hematological changes in all studied groups. a RBCS counts, b HGB concentrations, c WBCS counts. d PLT counts. Results were expressed as mean $\left(^{*}\right)$ compared with normal control, $\left(^{* *}\right)$ compared with $\mathrm{CCl}_{4}$ control, and showed a highly significant difference from control value at $(p<0.001)$ except for RBCs which was at $(p<0.05)$

its fast excretion, researchers have focused on ameliorative bioavailability in the most recent decade [69, 70]. Sulfonamides are the central and historically most prominent class of carbonic anhydrase inhibitors, being discovered in 1940, with many representatives in clinical use for decades [71]. Thus, we used sulfamethoxazole with curcumin in combination group (VIII, Table 1) to circumvent the problem of rapid metabolism and to improve its pharmacokinetics profile. The purpose of this study is to investigate the effect of each of curcumin (CUR) and sulfamethoxazole (SMX) either separate or together (CUR + SMX) on biochemical, hematological, and histological alternations associated with carbon tetrachloride (CCl4)-induced liver fibrosis in mice, and to explain the underlying mechanism. The $\mathrm{CCl}_{4}$ is a causative agent of numerous disarranges through its capabilityof causing oxidative stress and inflammation. $\mathrm{CCl}_{4}$ uses, through enzymes of the CYP 450 system, producing hepatotoxic metabolites for example, trichloromethyl radicals and trichloroperoxyl radicals. These metabolites cause hepatotoxicity through induction of lipid peroxidation that all together gives malondialdehyde (MDA) products that lead to hepatic injury [72]. According to our present data, $\mathrm{CCl}_{4}$ caused changes of several biomarkers which proved its hepatotoxic effects such as an increase in aminotransferases liver enzymes (ALT, AST), MDA, and NO, with a decrease in SOD, GSSG, TAO, GSH, total protein, and albumin compared to the negative control group (I, Table 1).

Oxidative stress is the most widely recognized instrument in organ injury. Oxygen is the primary particle for all cells for the creation of ATP, but it might, likewise can change into harmful species, for example reactive oxygen species. During aerobic respiration, the creation of free radicals could could bring about aging and cell death. Oxygen molecules are reduced by mitochondria to create superoxide ions or hydrogen peroxide $\left(\mathrm{H}_{2} \mathrm{O}_{2}\right)$. The superoxide and peroxide further respond with metal ions and produce hydroxyl radicals, which react with cell components including DNA and proteins. Polyphenolic curcumin is essentially appended to its antioxidant properties. CUR is seen as ten times more 


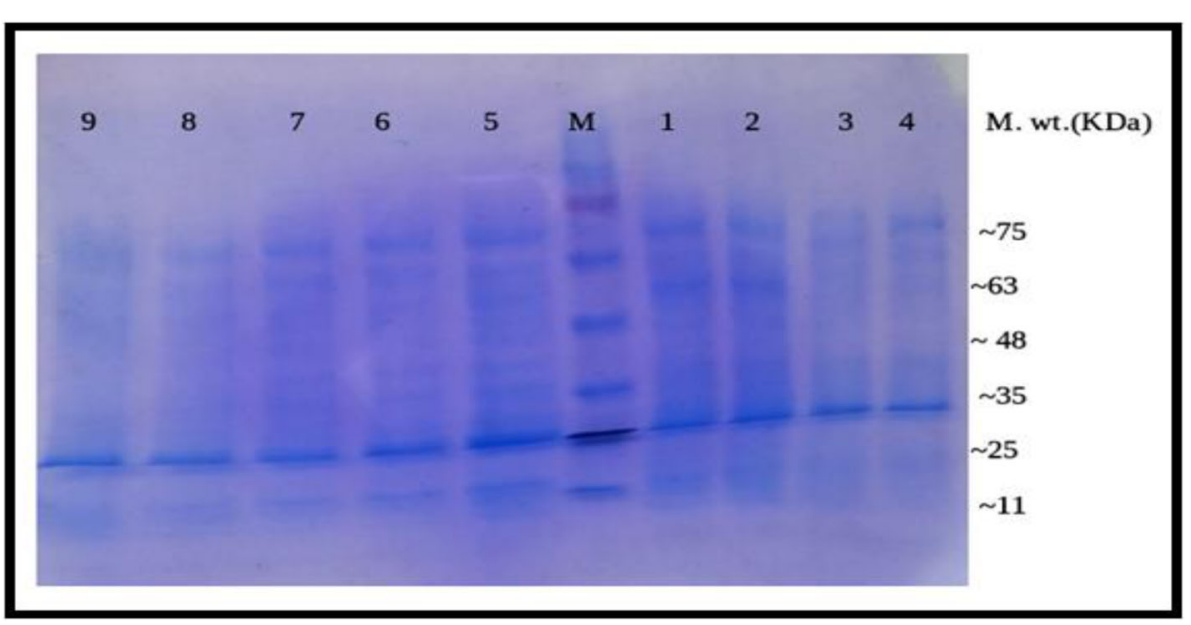

Fig. 9 SDS-Polyacrylamide gel of protein pattern of liver tissue samples. M = Marker 11-75 KDa, lanes 1-9: groups 1-9. Lane 1 represents the electrophoretic pattern of $\mathrm{CCl}_{4}$ group, lane 2 represents the electrophoretic pattern of sulfamethoxazole group, lane 3 represents the electrophoretic pattern of combination (curcumin + sulfamethoxazole) group, lane 4 represents the electrophoretic pattern of curcumin group, lane 5 represents the electrophoretic pattern of the DMSO control group, lane 6 represent the electrophoretic pattern of combination (curcumin + sulfamethoxazole) control group, lane 7 represents the electrophoretic pattern of sulfamethoxazole control group, lane 8 represents the electrophoretic pattern of curcumin control group, and lane 9 represent the electrophoretic pattern of the normal control group.

antioxidants than vitamin E [73]. CUR causes an increase in GSH concentration and activity of glutathione peroxidase and SOD. The glutathione and glutathione peroxidase act synergistically to scavenge free radicals. SOD scavenges superoxide radicals by changing over superoxide free radicals into $\mathrm{H}_{2} \mathrm{O}_{2}$ while staying away from the development of hydroxyl radicals. Thus, the $\mathrm{H}_{2} \mathrm{O}_{2}$ formed is expelled by the job of catalase or glutathione peroxidase. In this manner, SOD protects against free radical damage [74]. CUR has antioxidant properties that protect against $\mathrm{CCl}_{4}$-induced hepatic damage. It can repair all biomarkers against hepatic damage, i.e., decreasing level of ALT and AST, suppressing lipid peroxidation, decreasing MDA level, recovery of redox balance, and increasing level of reduced GSH [75].

Our results revealed that curcumin-treated group (IV, Table 1) had an increase in SOD, GSSG, TAO, GSH, total protein, and albumin, while it had a decrease in ALT, AST, MDA, and $\mathrm{NO}$ in comparison to $\mathrm{CCl}_{4}$ group (III, Table 1) which agreed with Zhao et al. [76], who reported that there was an increase in serum biomarkers of ALT, AST, and a decrease in the levels of albumin and the total protein, after treatment with CUR [76]. Indicators in liver disease, ALT and AST are hepatocyte cytosolic enzymes. An increase in levels of ALT and AST usually confirm liver injury. Albumin and total protein levels tend to be reduced in chronic liver injury because of the impaired ability of liver cells to synthesize proteins [76, 77]. Peng et al. [78] showed that curcumin pre-treatment at the doses of 50,100 , and $200 \mathrm{mg} / \mathrm{kg}$ markedly alleviated the expansion of MDA level brought about by $\mathrm{CCl}_{4}$ and it can up-manage the activities of SOD and levels of GSH. Momeni and Eskandari [79] showed that the use of curcumin alone significantly increased the total antioxidant capacity of serum in comparison with the control. Its direct antioxidant activity, CUR may enhance the synthesis of glutathione and improve the antioxidant defense system, a significant increase in the serum concentration of MDA. Curcumin affected the levels of peripheral blood parameters through increasing $\mathrm{HGB}, \mathrm{RBC}_{\mathrm{s}}$, PLT, and decreasing WBCs, which agreed with the results of Yin et al. [80]; however, the combination between CUR and SMX group (VIII, Table 1) had a significant increase in HGB, RBCs, and PLT and a significant decrease in WBCs, so the combination was more effective than curcumin alone. Sulfamethoxazole-treated group (VI, Table 1) caused an increase in SOD, GSSG, GSH, total protein, and albumin but caused a decreased in ALT, AST, MDA, and NO compared to the $\mathrm{CCL}_{4}$ group (III, Table 1) which was in agreement with Sahyon et al. [47]. Gupta et al. [81] reported that (sulfamethoxazole + selenium) treatment resulted in an increase in the activities of SOD, but caused a decrease $(p<0.001)$ in the levels of GSH when compared to diethylnitrosamine-treated animals and showed an increase in the levels of MDA. Also, Bottari et al. [40] reported that the treatments with SMX + trimethoprim, resveratrol, and inclusion complex in free forms or co-administered were able to reduce the total oxidation status and oxidation protein products levels in hepatic tissue of infected animals. In comparison, our results showed that curcumin and sulfamethoxazole combination have significantly, decreased MDA 

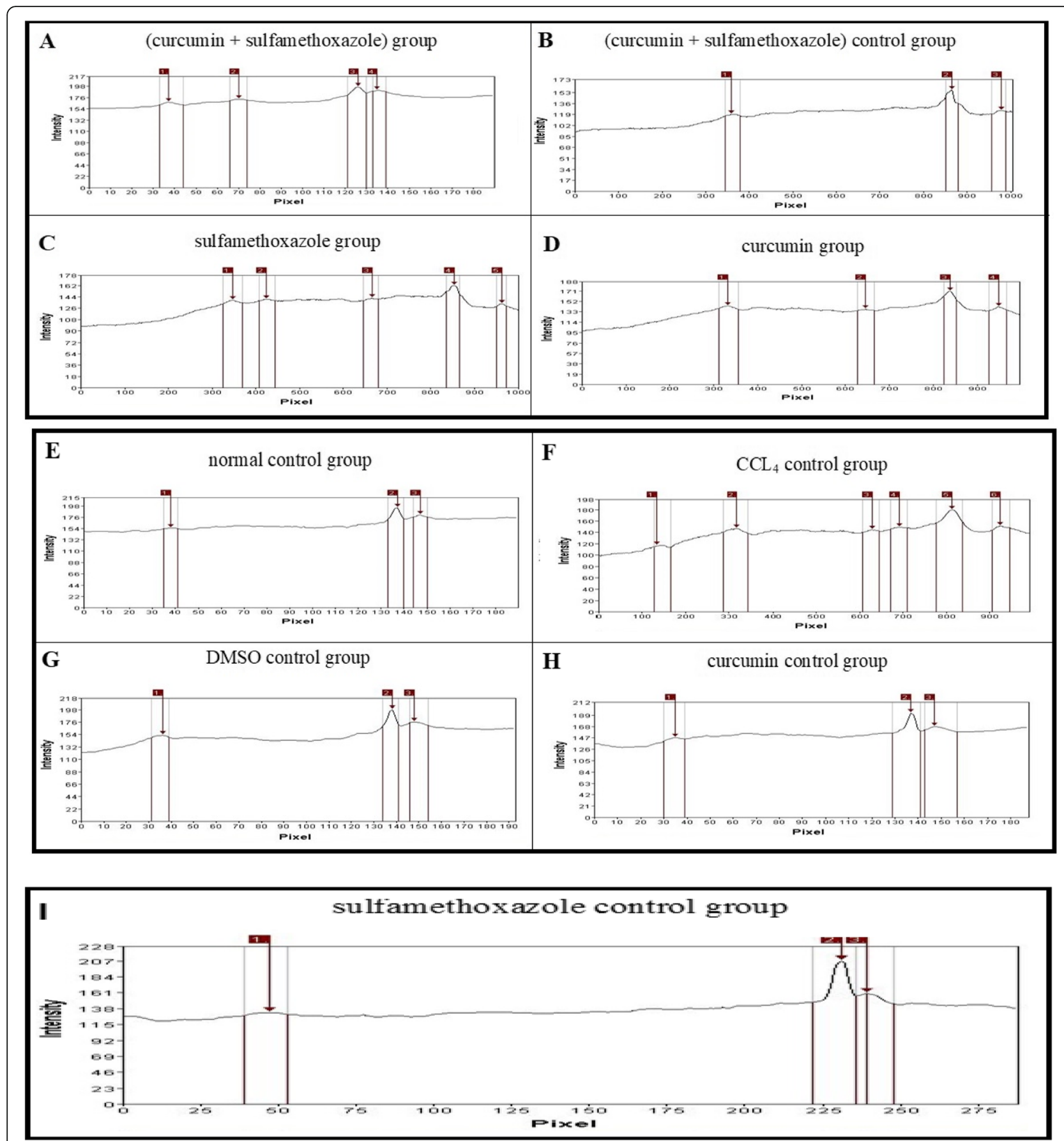

Fig. 10 Gel Pro analysis of protein pattern of liver tissue samples by SDS electrophoresis SDS of combination (curcumin + sulfamethoxazole) group (a), (curcumin + sulfamethoxazole) control group (b), sulfamethoxazole group (c), curcumin group (d), normal control group (e), $\mathrm{CCl}_{4}$ control group (f), DMSO control group (g) curcumin control group (h), sulfamethoxazole control group (i)

and NO levels, and increased SOD, GSSG, TAO, and GSH levels compared to the corresponding levels of the $\mathrm{CCl}_{4}$ control group.

The present data demonstrated an increase in protein synthesis in the $\mathrm{CCl}_{4}$ group with a corresponding decrease in the curcumin and/or sulfamethoxazole treated groups. This agreed with Thaloor et al. [82], who reported that the synthesis of proteins (including 60,36 , and $30.7 \mathrm{kDa}$ proteins) was inhibited in the presence of $25 \mu \mathrm{M}$ of curcumin. In a comparable study, Qin et al. [83] showed that the protein levels were significantly decreased in the CUR-treated groups. This, again, is in concurrence with our results. 


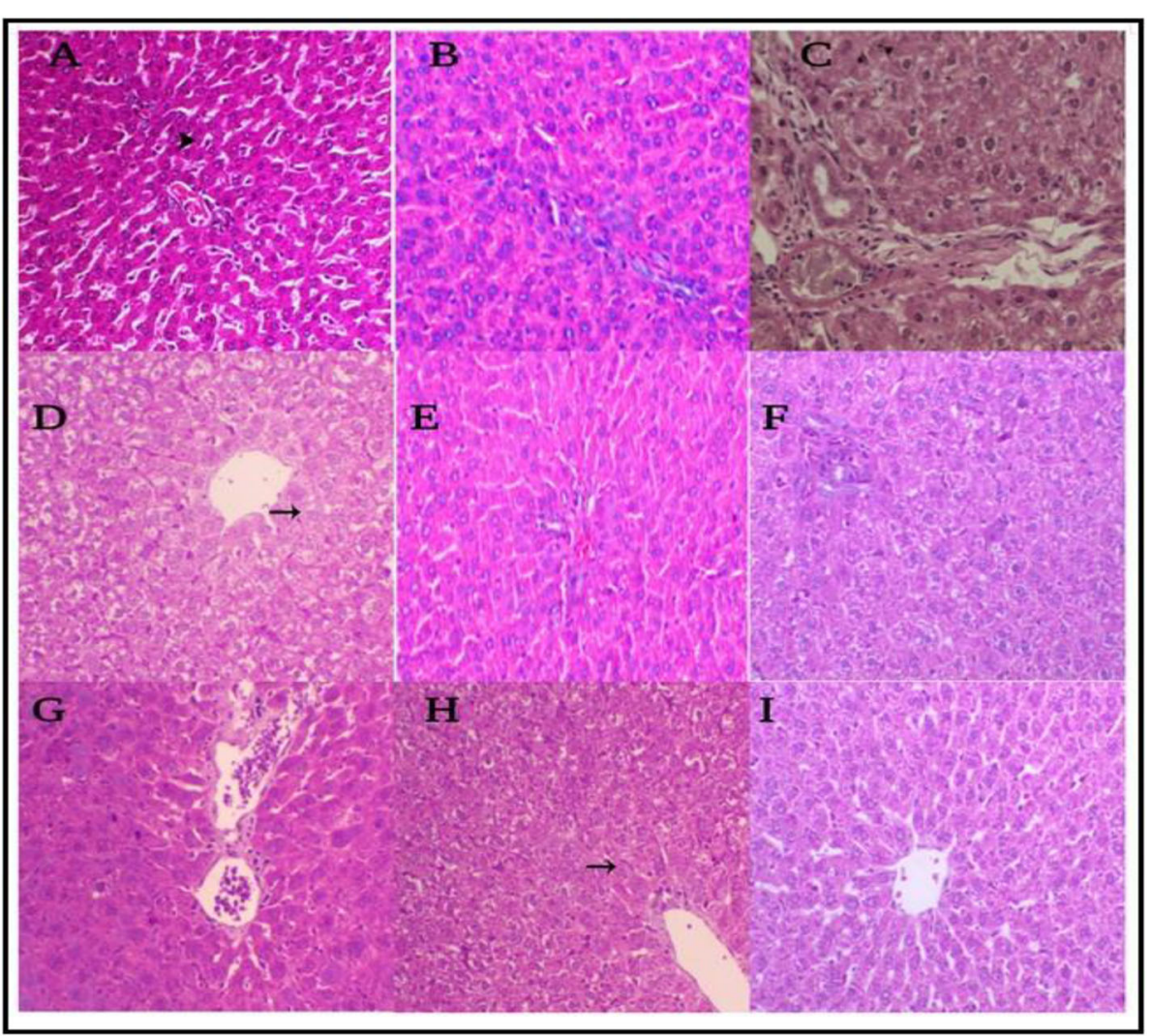

Fig. 11 A photomicrograph of the effects of CUR and SMX on CCl -induced liver fibrosis in Swiss mice, $\mathrm{H \& E}, \times 200,400$. a Normal hepatocytes around the portal area. $\mathbf{b}$ Normal liver structures. c Degenerative changes with an increased number of fibroblast and fibrosis. $\mathbf{d}$ Swelling of hepatocytes within the centrilobular area (arrow) in addition to a moderate degree of vacuolization of hepatocytes within the periportal area. $\mathbf{e}$ Normal liver structure. $\mathbf{f}$ Cloudy swelling and vacuolar degeneration of hepatocytes and mononuclear cells infiltration. $\mathbf{g}$ Normal liver structure. $\mathbf{h}$ Swelling and mild vacuolation of hepatocytes. i Normal liver structure

The histological examination of liver tissues showed that the liver of the control mice exhibited normal lobular architecture around the portal area. Treatment with $\mathrm{CCl}_{4}$ alone caused an increased number of fibroblasts and fibrosis. This agreed with Ahmad et al. [84] who reported that $\mathrm{CCl}_{4}$ treated group showed heavy cell infiltration, across the board vacuolated cytoplasm, darkly stained pyknotic and peripheral placed nuclei. Our results, also, agreed with Zhaoa et al. [21] which showed that the liver in $\mathrm{CCl}_{4}$ treated mice have a large number of hepatocytes necrosis, leukocytes infiltration, and damaged lobule structure and the liver in CUR treated mice have reduce leukocytes infiltration and reduced hepatocytes necrosis compared to the mice of the $\mathrm{CCl}_{4}$-positive control group, which agreed with our CUR treated group and showed cell swelling of hepatocytes within the centrilobular area (arrow), in addition to moderate degree of vacuolation of hepatocytes within the periportal area. The liver of the mice, in the curcumin and sulfamethoxazole combination group (CUR + SMX), showed cell swelling and mild vacuolation of hepatocytes. While the mice group that was treated with sulfamethoxazole (SMX) alone showed cloudy swelling, vacuolar degeneration of hepatocytes, and mononuclear cells infiltration. The above-mentioned results, clearly demonstrated the highly significant effect of curcumin and/or sulfamethoxazole against the harmful effect of $\mathrm{CCl}_{4}$ in dealing with Swiss mice group. However, further studies with different dosages and/or concentrations of curcumin and sulfamethoxazole will be done.

\section{Conclusions}

Treatment with curcumin and sulfamethoxazole either separately or together can reduce $\mathrm{CCl}_{4}$ hepatotoxicity in mice. Each of curcumin and sulfamethoxazole could be considered a promising candidate in the prevention and treatment of liver fibrosis.

\section{Abbreviations}

ALT: Alanine transaminase; AST: Aspartate transaminase; br: Broad; $\mathrm{CCl}_{4}$ : Carbon tetrachloride; CUR: Curcumin; DMSO: Dimethyl sulfoxide; d: Doublet; El: Electron impact; ECM: Extracellular matrix; GSSG: Glutathione reductase; HCT: Hematocrit value; HE: Hematoxylin-eosin; HGB: Hemoglobin concentration; HSC: Hepatic stellate cells; IR: Infrared; MDA: Malondialdehyde; MS: Mass spectral; NO: Nitric oxide; NMR: Nuclear magnetic resonance; PLT: Platelets count; KBr: Potassium bromide; RBCs: Red blood cells count; 
GSH: Reduced glutathione; s: Singlet; SDS-PAGE: Sodium dodecyl sulphate polyacrylamide gel electrophoresis; SMX: Sulfamethoxazole; SOD: Superoxide dismutase; TMS: Tetramethylsilane; m.p.: The melting point; TAO: Total antioxidant activity

\section{Acknowledgments}

We would like to thank Amira Ragheb, CT, ASCP for her effort in editing the final paper.

\section{Authors' contributions}

R.Z, ZG, and MM conceived and designed experiments; R.Z, Z.B, A.T, and M.M contributed to the analysis and/or interpretation of data. R.Z and Z.G drafted the manuscript and R.Z, ZG, MM, and A.T revised it critically for important intellectual content. All authors have read the manuscript and approved the submission.

\section{Funding}

This research did not receive any specific grant from funding agencies in the public, commercial, or not-for-profit sectors.

\section{Availability of data and materials}

Authors declare that all generated and analyzed data are included in the article.

\section{Ethics approval and consent to participate}

All animal experiments conformed to the British Home Office Regulations (Animal Scientific Procedures Act 1986) and associated guidelines, EU Directive 2010/63/EU for animal experiments.

The Experimental research on mice approved by the international recommendations for the care and use of animals, and both maintenance and feeding were similar for all animals and remained in accordance with proper animal welfare guidelines for the care and use of mice. This work launched after attaining a permission of scientific and ethical committees from Damietta University, research approval code is 3.2.3.3. Biochemical studies on liver diseases.

Ethics committee reference numbers

Research approval code is 3.2.3.3. Biochemical studies on liver diseases and this is the available in our university.

\section{Consent for publication}

Not applicable

\section{Competing interests}

The authors declare that they have no competing interests.

\section{Author details}

'Department of Chemistry (Biochemistry division), Faculty of Science, Damietta University, New Damietta, Egypt. ${ }^{2}$ Department of Microbial Biotechnology, Division of Genetic Engineering and Biotechnology, National Research Centre, Cairo 12622, Egypt. ${ }^{3}$ Department of Chemistry, Faculty of Science, Damietta University, New Damietta, Egypt.

Received: 19 January 2020 Accepted: 30 March 2020

\section{Published online: 04 May 2020}

\section{References}

1. Adewusi EA, Afolayan AJ (2010) A review of natural products with hepatoprotective activity. J Med Plants Res 4(13):1318-1334

2. Wang FS, Fan JG, Zhang Z, Gao B, Wang HY (2014) The global burden of liver disease: the major impact of China. Hepatology 60:2099-2108

3. Gines P, Cardenas A, Arroyo V, Rodes J (2004) Management of cirrhosis and ascites. N Engl J Med 350(16):1646-1654

4. Friedman SL (2003a) Liver fibrosis from bench to bedside. J Hepatol 38:38-53

5. Wells RG (2006) Mechanisms of liver fibrosis: new insights into an old problem. Drug Disco Today Dis Mech 3(4):489-495

6. Friedman SL (2000b) Molecular regulation of hepatic fibrosis, an integrated cellular response to tissue injury. J Biol Chem 275(4):2247-2250

7. Scholten D, Trebicka J, Liedtke C, Weiskirchen R (2015) The carbon tetrachloride model in mice. Lab Anim 49(1):4-11
8. Uehara T, Pogribny I, Rusyn I (2014) The DEN and CCl 4 -induced mouse model of fibrosis and inflammation-associated hepatocellular carcinoma. Curr Protoc Pharmacol 66:14.30.1-14.30.10

9. Juarez FJ, Vazquez MLR, Sanchez ARR, Martínez MC, Ortiz GG, Llamas J, Posadas FA, Reyes $J$ (2008) Acute renal failure induced by carbon tetrachloride in rats with hepatic cirrhosis. Ann Hepatol 7(4):331-338

10. Shaker ME, Zalata KR, Mehal WZ, Shiha GE, Ibrahim TM (2011) Comparison of imatinib, nilotinib, and silymarin in the treatment of carbon tetrachlorideinduced hepatic oxidative stress, injury, and fibrosis. Toxicol App Pharmacol 252(2):165-175

11. Weber L, Boll M, Stampfl M (2003) Hepatotoxicity and mechanism of action of haloalkanes: carbon tetrachloride as a toxicological model. Crit Rev Toxicol 33(2):105-136

12. Teiten M, Dicato M, Diederich M (2014) Hybrid curcumin compounds: a new strategy for cancer treatment. Molecules 19(12):20839-20863

13. Aggarwal BB, Sundaram C, Malani N, Ichikawa H (2007) Curcumin: the Indian solid gold. Adv Exp Med Biol 595:1-75

14. Tien LH, Soon HY (2018) Anticancer effect of curcumin on breast cancer and stem cells. Food Sci Hum Wellness 7(2):134-137

15. Benzer F, Kandemir F, Kucukler S, Comakl S, Caglayan C (2018) Chemoprotective effects of curcumin on doxorubicin-induced nephrotoxicity in wistar rats: by modulating inflammatory cytokines, apoptosis, oxidative stress and oxidative DNA damage. Arch Physiol Biochem 124(5):448-457

16. Ameida M, Sampaio G, Basstos D, Villavicencia A (2018) Effect of gamma radiation processing on turmeric: Antioxidant activity and curcumin content. Radiat Phys Chem 152:12-16

17. Khwaja S, Fatima K, Hassanain BC, Kour A, Singh A, Luqman S, Sarkar J Chanda D, Shanker K, Gupta A, Mondhe D, Negi A (2018) Antiproliferative efficacy of curcumin mimics through microtubule destabilization. Eur J Med Chem 10:51-61

18. Afolayan F, Erinwusi B, Oyeyemi O (2018) Immunomodulatory activity of curcumin-entrapped poly d,l-lactic-co-glycolic acid nanoparticles in mice. Integr Med Res 7(2):168-175

19. Reyes-Gordillo K, Shah R, Lakshman M, Flores-Beltran R, Muriel P (2017) Chapter 49 Hepatoprotective properties of curcumin. Liver Pathophysiology Therapies and Antioxidants:687-704

20. Sun J, Chen F, Braun C, Zhou Y, Rittner H, Tian Y, Cai X, Ye D-W (2018) Role of curcumin in the management of pathological pain. Phytomedicine 48: $129-140$

21. Zhaoa X, Cheng G, Liu Y, Chen $Y$, Wud H, Xiong $Y$, Wange $G$, Jiae $B$, Lie $Y$, Xie J, Wange J, Yang X, Zhang Z, Huang R, Wu C (2018) Curcumin reduces Ly6Chi monocyte infiltration to protect against liver fibrosis by inhibiting Kupffer cells activation to reduce chemokines secretion. Biomed Pharmacother 106:868-878

22. Fier P, Maloney K (2019) NHC-Catalyzed deamination of primary sulfonamides: a platform for late-stage functionalization. J Am Chem Soc 141(4):1441-1445

23. Brunton LL, Lazo JS, Parken KL (eds) (2006) Goodman \& Gilman's: The pharmacological bases of therapeutics, 11th edn. New York: McGraw-Hill, pp 1111-1119

24. Buğday N, Küçükbay FZ, Küçükbay H, Bua S, Bartolucci G, Leitans J, Kazaks A Tars K, Supuran CT (2018) Synthesis of novel dipeptide sulfonamide conjugates with effective carbonic anhydrase I, II, IX, and XII inhibitory properties. Bioorg Chem 81:311-318

25. Mizdal C, Stefanello S, da Costa FV, Agertt V, Bonez P, Rossi G, da Silva T, FéAlexandre A, de Lourenço ML, de Campos MMA (2018) The antibacterial and anti-biofilm activity of gold-complexed sulfonamides against methicillin-resistant Staphylococcus aureus. Microb Pathogenesis 123:440448

26. Kumar K, Vedavathi P, Subbaiah K, Reddy D, Raju C (2017) Design, synthesis, spectral characterization and bioactivity evaluation of new sulfonamide and carbamate derivatives of 5-Nitro-1H-indazole. Org Commun 10(3):239-249

27. Okolotowicza K, Dwyera M, Ryana D, Chenga J, Cashmana E, Moorea S, Mercolab M, Cashman J (2018) Novel tertiary sulfonamides as potent anticancer agents. Bioorgan Med Chem 26:4441-4451

28. Abdel-Maksoud M, El-Gamal M, El-Din M, Choi Y, Choi J, Shin J, Kang S, Yoo K, Lee K, Baek D, Oh C (2018) Synthesis of new triarylpyrazole derivatives possessing terminal sulfonamide moiety and their inhibitory effects on PGE2 and nitric oxide productions in lipopolysaccharide-induced RAW 264.7 macrophages. Molecules 23(10):2556 
29. Sonpavde G, Hutson TE (2007) Pazopanib: a novel multitargeted tyrosine kinase inhibitor. Curr Oncol Rep 9(2):115-119

30. Talley JJ, Brown DL, Carter JS, Graneto MJ, Koboldt CM, Masferrer JL, Perkins WE, Rogers RS, Shaffer AF, Zhang YY, Zweifel BS, Seibert K (2000) 4-[5-Methyl-3-phenylisoxazol-4-yl]- benzenesulfonamide, valdecoxib: a potent and selective inhibitor of COX-2. J Med Chem 43(5):775-777

31. Engelhardt EL, Thominet ML (1969) Sulpiride synthesis. U.S: Patent, 3342826

32. Ozawa Y, Kusano K, Owa T, Yokoi A, Asada M, Yoshimatsu K (2012) Therapeutic potential and molecular mechanism of a novel sulfonamide anticancer drug, indisulam (E7070) in combination with CPT-11 for cancer treatment. Cancer Chemother Pharmacol 69(5):1353-1362

33. Penning T, Tally J, Bertenshaw S, Carter J, Collins P, Doctor S, Graneto M, Lee L, Malecha J, Miyashiro J, Rogers R, Rogier D, Yu S, Anderson G, Burton E, Cogburn J, Gregory S, Koboldt C, Perkins W, Seibert K, Veenhuizen A, Zhang Y, Isakson P (1997) Synthesis and biological evaluation of the 1,5diarylpyrazole class of cyclooxygenase-2 inhibitors: identification of 4-[5-(4methyl phenyl)-3- (trifluoromethyl)-1H-pyrazol-1-yl] benzenesulfonamide (SC-58635, celecoxib). J Med Chem 40:1347-1365

34. Stams T, Chen Y, Boriack-Sjodin P, Hurt J, Liao J, May J, Dean T, Laipis P, Silverman D, Christianson D (1998) Structures of murine carbonic anhydrase IV and human carbonic anhydrase II complexed with brinzolamide: molecular basis of isozyme-drug discrimination. Protein Sci 7(3):556-563

35. Mizuno C, Chittiboyina A, Kurtz T, Pershadsingh H, Avery M (2008) Type 2 diabetes and oral antihyperglycemic drugs. Curr Med Chem 15(1):61-74

36. Ward K, Gill J (1997) Dofetilide: first of a new generation of class III agents. Exp Opin Invest Drugs 6(9):1269-1281

37. Van Berkel MA, Elefritz JL (2018) Evaluating off-label uses of acetazolamide. Am J Health Syst Pharm 75:524-531

38. Fernstrom J, Munger S, Sclafani A, de Araujo I, Roberts A, Molinary S (2012) Mechanisms for Sweetness. J Nutr 142(6):1134S-1141S

39. Dodd M, Huang C (2004) Transformation of the antibacterial agent sulfamethoxazole in reactions with chlorine: kinetics, mechanisms, and pathways. Environ Sci Technol 38:5607-5615

40. Bottari N, Baldissera M, Tonin A, Rech V, Alves C, D'Avila F, Thomé G, Guarda N, Moresco R, Camillo G, Vogel F, Lucchese C, Schetinger M, Morsch V, Tochetto C, Fighera R, Nishihira V, Da Silva A (2016) Synergistic effects of resveratrol (free and inclusion complex) and sulfamethoxazole-trimethoprim treatment on pathology, oxidant/antioxidant status and behavior of mice infected with Toxoplasma gondii. Microb Pathogenesis 95:166-174

41. Nakashima K, Aoshima M, Nakashita T, Hara M, Otsuki A, Noma S, Misawa M, Otsuka Y, Motojima S (2018) Low-dose trimethoprim-sulfamethoxazole treatment for pneumocystis pneumonia in non-human immunodeficiency virus-infected immunocompromised patients: A single-center retrospective observational cohort study. J Microbiol. Immunol 51(6):810-820

42. Ahmed M, Abdul Qadir M, Shafiq M, Muddassar M, Hameed A, Arshad M, Asiri A (2017) Curcumin: synthesis optimization and in silico interaction with cyclin-dependent kinase. Acta Pharm 67:385-395

43. Wichitnithad W, Nimmannit U, Wacharasindhu S, Rojsitthisak P (2011) Synthesis, characterization and biological evaluation of succinate prodrugs of curcuminoids for colon cancer treatment. Molecules 16:1888-1900

44. Pabon H (1964) A synthesis of curcumin and related compounds. Recueil 83:379

45. Den Hartogh DJ, Gabriel A, Tsiani E (2019) Antidiabetic properties of curcumin II: evidence from in vivo studies. Nutrients 12(1):58

46. Kabirifara R, Ghoreshia Z, Rezaifarb A, Bineshc F, Bamdadd K, Moradia A (2018) Curcumin, quercetin and atorvastatin protected against the hepatic fibrosis by activating AMP-activated protein kinase. J Funct Foods 40:341-348

47. Sahyon H, Ramadan E, Mashaly M (2019) Synergistic effect of quercetin in combination with sulfamethoxazole as new antibacterial agent: invitro and invivo study. J Pharm Chem 53(9):803-813

48. Montgomery H, Dymock J (1961) The determination of nitrate in water. Analyst 86:414-416

49. Goldberg D, Spooner R (1983) In: Bergmeyer HV (ed) Assay of glutathione reductase. Methods of Enzymatic Analysis. Verlag Chemie: Weinheim, Germany, pp 258-265

50. Reitman S, Frankel S (1957) A colorimetric method for the determination of serum glutamic oxalacetic and glutamic pyruvic transaminases. Am J Clin Pathol 28(1):56-63

51. Gornall A, Bardawill C, David M (1949) Determination of serum proteins by means of the biuret reaction. J Biol Chem 177(2):751-766
52. Doumas B, Watson W, Biggs H (1971) Albumin standards and the measurement of serum albumin with promo cresol green. Clin Chim Acta 31(1):87-96

53. Nishikimi M, Appaji N, Yogi K (1972) The occurrence of superoxide anion in the reaction of reduced phenazine methosulfate and molecular oxygen. Biochem Biophys Res Commun 46(2):849-854

54. Beutler E, Duron O, Kelly B (1963) Improved method for the determination of blood glutathione. J Lab Clin Med 61:882-890

55. Koracevic D, Koracevic G, Djordjevic V, Andrejevic S, Cosic V (2001) Method for the measurement of antioxidant activity in human fluids. J Clin Pathol 54(5):356-361

56. Satoh K (1978) Serum lipid peroxide in cerebrovascular disorders determined by a new colorimetric method. Clin Chim Acta 90(1):37-43

57. Rubio C, Hernández-Ruiz J, Martinez-Subiela S, Tvarijonaviciute A, Ceron J (2016) Spectrophotometric assays for total antioxidant capacity (TAC) in dog serum: an update. BMC Vet Res 12:166

58. Laemmli U (1970) Cleavage of structural proteins during the assembly of the head of bacteriophage T4. Nature. 227(5259):680-685

59. Andrews A (1986) Electrophoresis: theory, techniques, and biochemical and clinical application. Oxford Science Publications Clarendon Press, Oxford, p 452

60. Oner-lyidogan Y, Kocak H, Seyidhanogiu M, Gurdol F, Gulcubuk A, Yildirim F, Cevik A, Uysal M (2013) Curcumin prevents liver fat accumulation and serum fetuin-A increase in rats fed a high-fat diet. J Physiol Biochem 69(4): $677-686$

61. Feng J, Liu Z (2009) Phenolic and enolic hydroxyl groups in curcumin: which plays the major role in scavenging radicals? J Agric Food Chem 57: 11041-11046

62. Anderson A, Mitchell M, Mohan R (2000) Isolation of curcumin from turmeric. J Chem Educ 77(3):359

63. Rohman A, Sudjadi D, Ramadhani D, Nugroho A (2015) Analysis of curcumin in curcuma longa and curcuma xanthorriza using FTIR spectroscopy and chemometrics. J Med Plants Res 9(4):179-186

64. Youssef K, Ezzo A, El-Sayed M, Hazzaa A, El-Medany A, Arafa M (2015) Chemopreventive effects of curcumin analogs in DMH-Induced colon cancer in albino rats model. J Pharm Sci 1:57-72

65. Valand N, Manishkumar P, Menon S (2015) Curcumin-p-sulfonatocalix [4] resorcinarene (p-SC [4] R) interaction: thermo-physico chemistry, stability, and biological evaluation. RSC Adv 5:8739-8752

66. Mohan PR, Sreelakshmi G, Muraleedharan CV, Joseph R (2012) Water soluble complexes of curcumin with cyclodextrins: characterization by FT-Raman spectroscopy. Vib spectrosc 62:77-84

67. Silverstein R, Bassler G, Morrill T (1981) Spectrometric identification of organic compounds, 4th edn. Wiley, New York, p 442

68. Williams D, Fleming I (1980) Spectroscopic methods in organic chemistry. London, New York, McGraw-Hill, p 251.

69. Jamwal R (2018) Bioavailable curcumin formulations: a review of pharmacokinetic studies in healthy volunteers. J Integr Med 16(6):367-374

70. Noureddin S, El-Shishtawy R, Al-Footy K (2019) Curcumin analogues and their hybrid molecules as multifunctional drugs. Eur J Med Chem 182: 111631

71. Ramya PVS, Angapelly S, Angeli A, Digwal C, Arifuddin M, Babu B, Supuran CT, Kamal A (2017) Discovery of curcumin inspired sulfonamide derivatives as a new class of carbonic anhydrase isoforms I, II, IX, and XII inhibitors. J Enzym Inhib Med Ch 32(1):1274-1281

72. Oyinloye B, Osunsanmi F, Ajiboye B, Ojo O, Kappo A (2017) Modulatory effect of methanol extract of piper guineense in $\mathrm{CCl}_{4}$-induced hepatotoxicity in male rats. Int J Env Res Pub He 14:955

73. Jaeschke H, McGill M, Ramachandran A (2012) Oxidant stress, mitochondria, and cell death mechanisms in drug-induced liver injury: lessons learned from acetaminophen hepatotoxicity. Drug Metab Rev 44:88-106

74. Jagetia G, Rajanikant $G$ (2015) Curcumin stimulates the antioxidant mechanisms in mouse skin exposed to fractionated $y$-irradiation. Antioxidants 4:25-41

75. Khan H, Ullah H, Nabavi S (2019) Mechanistic insights of hepatoprotective effects of curcumin: Therapeutic updates and future prospects. Food Chem Toxicol 124:182-191

76. Zhao Y, Ma X, Wang J, He X, Hu Y, Zhang P, Wang R, Li R, Gong M, Luo S, Xiao X (2014) Curcumin protects against $\mathrm{CCl}_{4}$-induced liver fibrosis in rats by inhibiting HIF-1a through an ERK-dependent pathway. Molecules 19: 18767-18780 
77. Devi SL, Viswanathan P, Anuradha CV (2009) Taurine enhances the metabolism and detoxification of ethanol and prevents hepatic fibrosis in rats treated with iron and alcohol. Environ Toxicol Phar 27:120-126

78. Peng X, Dai C, Liu Q, Li J, Qiu J (2018) Curcumin attenuates on carbon tetrachloride-induced acute liver injury in mice via modulation of the Nrf2/ HO-1 and TGF- $\beta 1 / S m a d 3$ pathway. Molecules 23(1):215

79. Momeni H, Eskandari N (2017) Effect of curcumin on kidney histopathological changes, lipid peroxidation and total antioxidant capacity of serum in sodium arsenite-treated mice. Exp Toxicol Pathol 69(2):93-97

80. Yin H, Guo R, Xu Y, Zheng Y, Hou Z, Dai X, Zhang Z, Zheng D, Xu H (2012) Synergistic antitumor efficiency of docetaxel and curcumin against lung cancer. Acta Bioch Bioph Sin 44:147-153

81. Gupta R, Anwar F, Khosa RL (2013) The effect of sulfamethoxazole and selenium on antioxidant defense system in the blood of rats treated with DEN. IOSR JPBS 8:29-37

82. Thaloor D, Singh A, Sidhu G, Prasad P, Kleinman H, Maheshwari R (1998) Inhibition of angiogenic differentiation of human umbilical vein endothelial cells by curcumin. Cell Growth Differ 9:305-312

83. Qin L, Qin J, Zhen X, Yang Q, Huang L (2018) Curcumin protects against hepatic stellate cells activation and migration by inhibiting the CXCL12/ CXCR4 biological axis in liver fibrosis: A study in vitro and in vivo. Biomed Pharmacother 101:599-607

84. Ahmad S, Rehman M, Fatima B, Ahmad B, Hussain I, Ahmad S, Farooq A, Muzamil S, Razzaq R, Rashid S, Bhat S, Mir M (2018) Antifibrotic effects of Dlimonene (5(1-methyl-4-[1-methylethenyl]) cyclohexane) in $\mathrm{CCl}_{4}$ induced liver toxicity in Wistar rats. Environ Toxicol 33:361-369

\section{Publisher's Note}

Springer Nature remains neutral with regard to jurisdictional claims in published maps and institutional affiliations.

\section{Submit your manuscript to a SpringerOpen ${ }^{\odot}$ journal and benefit from:}

- Convenient online submission

- Rigorous peer review

- Open access: articles freely available online

High visibility within the field

- Retaining the copyright to your article

Submit your next manuscript at $\boldsymbol{\nabla}$ springeropen.com 